\title{
Begging on the Streets of Eighteenth-Century London
}

\author{
Tim Hitchcock
}

A

nyone pretending to gentility in eighteenth-century London knew that giving to a beggar on the street was a delicate and complex maneuver. ${ }^{1}$ Erasmus Jones in his cutting 1737 guide to urban etiquette, The Man of Manners; or, Plebeian Polished, observed that he had "seen some people . . . dispensed their charities with so unhandsome a grace, that methought they did ill in doing good, and refus'd an alms while they gave one." Jones complained that unpracticed almsgivers "seemed to insult over a poor creature's misery and seldom open'd their purse till they had vented their gall," and he advised that "a kind compassionate look, oftentimes refreshes more than a crown.. . . The very manner of giving adds to the gift." ${ }^{2}$ For the bewigged and tutored, leisured, and fashion-conscious denizens of eighteenth-century London, the calls of pity had to be answered with just the right combination of sympathy and disdain, just the right flourish of lace and charity.

If the part played by the almsgivers was complex and difficult, if their lines needed rehearsing and their gestures practice, how much more difficult was it to play the central character in this most common scene? For the beggar, how you asked, and who, where you asked, and what you asked for all needed to be finely judged. How you held your body and pitched your voice, whether you stood or sat, exposed cankers and sores or modestly hid them beneath rags all needed to be considered. Whether you sought alms from the estates of the dead or at kitchen doors, whether you chose to beg at Christmas or May Day, whether you asked

Tim Hitchcock is professor of eighteenth-century history at the University of Hertfordshire. He has published widely on the histories of eighteenth-century British poverty and sexuality, and he is the codirector of the Old Bailey Online (www.OldBaileyOnline.org).

${ }^{1}$ There is an extensive and growing literature on politeness in the eighteenth century. It does not, however, explicitly treat the issue of begging. For a guide to the development of "politeness," see Lawrence E. Klein, "Politeness and the Interpretation of the British Eighteenth Century," Historical Journal 45, no. 4 (2002): 869-98; Paul Langford, "The Uses of Eighteenth-Century Politeness," Transactions of the Royal Historical Society, 6th ser., 12 (2002): 311-31.

${ }^{2}$ Erasmus Jones, The Man of Manners; or, Plebeian Polish'd (London, 1737), 2.

Journal of British Studies 44 (July 2005): 478-498

(C) 2005 by The North American Conference on British Studies.

All rights reserved. 0021-9371/2005/4403-0004\$10.00 
for cold cash or warm food all reflected a series of finely judged decisions based in a complex and changing culture of obligation and right. This was a culture in which gender, age, and physical dis/ability played crucial roles in the creation of a compelling case for relief. It was a culture in which location, accent, and time of year could determine whether a few pence were doled out or the heavy hand of the law used to take up the supplicant as a vagrant. It was also a culture in which the boundaries between work and charity were gray and indistinct-in which children and apprentices frequently took on a begging role, while beggars used the accoutrement of hard work to justify their place on the streets.

This article will describe how to beg. It will examine the annual rhythms of begging and the different ways in which beggars expressed their demands. By looking at Christmas boxes and holidays, weddings and funerals, each with its own form of ritualized begging, it will tie mendicity into a complex popular culture that continued to be shared by all classes. It will also provide descriptions of how to beg for food and work at kitchen doors and for money on the streets. It will contribute to a brief and partial taxonomy of begging, a vade mecum for the destitute. In the process, it will suggest that the underlying cultures of obligation at the heart of these exchanges have been unreasonably ignored by historians. Although legislators and many pamphlet writers bemoaned the existence of beggars on the streets of London and pushed for their imprisonment and reform, a long-standing culture of mutual obligation and charity ensured that beggars were able to retain their freedom to knock on kitchen doors and stand at street corners. ${ }^{3}$

Throughout the early modern period, begging served as a central contradiction in the formulation of social policy. It was both outlawed and encouraged. The sixteenth-century story of the development of antivagrancy legislation is well known. The imposition of the death penalty for repeated acts of vagrancy is simply the high (or low) point in a narrative of repression. ${ }^{4}$ But even in the eighteenth century begging remained illegal and subject to a wide range of punishments. During the course of the century, there were some twenty-six new pieces of vagrancy legislation that collectively made legal responses to begging ever more severe. Imprisonment at hard labor, whipping, and removal were regularized and by the 1790s made mandatory for men, at least. Rewards for apprehending beggars rose from two shillings each to five shillings in 1744, with the proviso that ten shillings could be awarded in special circumstances. ${ }^{5}$ Many of these developments

\footnotetext{
${ }^{3}$ Begging as a form of behavior has been very little studied by historians. There are, however, several excellent recent articles on the administration and impact of social policy in relation to begging. In particular, see M. J. D. Roberts, "Reshaping the Gift Relationship: The London Mendicity Society and the Suppression of Begging in England, 1818-69," International Review of Social History 36 (1991): 201-31, and "Public and Private in Early Nineteenth-Century London: The Vagrant Act of 1822 and Its Enforcement," Social History (London) 13 (1988): 273-94; Nicholas Rogers, "Policing the Poor in Eighteenth-Century London: The Vagrancy Laws and Their Administration," Histoire sociale/Social History 24 (1991): 127-47. For a recent attempt to view begging from a practitioner's perspective, see Norbert Schindler, Rebellion, Community and Custom in Early Modern Germany, trans. Pamela E. Selwyn (Cambridge, 2002), chap. 6.

${ }^{4}$ See A. L. Beier, Masterless Men: The Vagrancy Problem in England, 1560-1640 (London, 1985); Paul Slack, "Vagrants and Vagrancy in England, 1598-1664," in Migration and Society in Early Modern England, ed. Peter Clark and David Souden (London, 1987), 49-76.

${ }^{5}$ See Rogers, "Policing the Poor," 128-31.
} 
have been seen through the lens of the gradual growth of new institutions, of reformatory prisons and workhouses, and have been analyzed as a component of an ever more effective state apparatus. The languages of reform and punishment found in elite discussions of vagrancy and made material in the cold stone walls of Britain's new prisons and workhouses have seemed to imply that the state could and did impose its will on beggars. ${ }^{6}$ And it is certainly true that thousands of women, men, and children were removed under the vagrancy statutes each year, a proportion of whom were also set to hard labor.

Careful attention to the rhetorics of charity have simply underlined this impression of growing control. Casual charity given at the roadside was increasingly condemned and the provision of more discriminating institutions advocated. The extent to which a beggar could be seen in the light of an inhuman other, a social problem requiring new institutions, rather than as a fellow sufferer in the travails of life is reflected in Adam Smith's complete refusal to encompass sympathy for beggars in his Theory of Moral Sentiments. In Smith's jaundiced view, "We despise a beggar; and though his importunities may extort an alms from us, he is scarce ever the object of any serious commiseration." Eighteenth-century humor similarly reflects the extent to which beggars frequently attracted the contempt of their contemporaries. Jests in which beggars formed the cruel butt of pranks and insults were a staple of eighteenth-century joke books. ${ }^{8}$ And when Francis Place confronted the difficult choices his own poverty condemned him to, he declared, "I knew well that to enable me to make money I must consent to submit to much indignity, and insolence, to tyranny and injustice. I had no choice between doing this and being a beggar, and I was resolved not to be a beggar." The great charitable institutions of the period, the Foundling Hospital, the Magdalen, and the Marine Society, were seen as partial solutions to the "problem" of begging.

We need to be careful, however, not to overstate the influence of these condemning discourses on day-to-day behavior. Just as Donna Andrew, for instance, has found a newly censorious tone in the charity sermons drafted for the benefit of the associational charities of midcentury, there was also a strong counterculture of criticism directed at those who would deny the Christian duty to relieve beggars wherever they were found. ${ }^{10}$ It was a commonplace criticism of the clergy pointing up both their hypocrisy and their heightened duty to the beggarly poor that

\footnotetext{
${ }^{6}$ For the now classic statement of the evolution of prisons, see Michael Ignatief, A Just Measure of Pain: The Penitentiary in the Industrial Revolution, 1750-1850 (London, 1978).

${ }^{7}$ Adam Smith, The Theory of Moral Sentiments (1759; Amherst, NY, 2000), 202; citations from 2000 edition.

${ }^{8}$ For an excellent recent article on the objects and cruelty of eighteenth-century humor, see Simon Dickie, "Hilarity and Pitilessness in the Mid-Eighteenth Century: English Jestbook Humor," EighteenthCentury Studies 37, no. 1 (2003): 1-22.

${ }^{9}$ Francis Place, The Autobiography of Francis Place (London, 1771-1854), ed. Mary Thale (Cambridge, 1972), 216.

${ }^{10}$ See Donna T. Andrew, Philanthropy and Police: London Charity in the Eighteenth Century (Princeton, NJ, 1989), chaps. 2, 5; Paul Slack, From Reformation to Improvement: Public Welfare in Early Modern England (Oxford, 1999), chap. 7. For a brilliant treatment of the evolution of attitudes toward charity in this period, see Deborah Valenze, "Charity, Custom and Humanity: Changing Attitudes towards the Poor in Eighteenth-Century England," in Revival and Religion since 1700, Essays for John Walsh, ed. John Garnett and Colin Matthews (London, 1993), 59-78.
} 
"charity in the street may beg two hours of a clergy-man before she will get the tythe of two-pence-half-penny to succour her babes." ${ }^{11}$ And at midcentury Henry Fielding complained bitterly that "mankind are so forward to relieve the appearance of distress in their fellow-creates, that every beggar, who can but moderately well personate misery, is sure to find relief and encouragement; and this, though the giver . . . can scarce be ignorant that his bounty is illegal and that he is encouraging a nuisance." ${ }^{12}$ Despite the existence of dozens of new institutions and discriminating charities, despite the thousands of vagrants removed each year, it is clear that some forms of begging were always acceptable, even encouraged, and that many people were able to maintain a life on the streets in relative security, in contradiction to the will of the state and the letter of the law.

We cannot know the actual numbers of beggars on London's streets. Like unrecorded crime, unprosecuted begging leaves few traces in the archives. But in 1796 Matthew Martin collected information that allows us to make a well-educated guess. In that year he had six thousand tickets printed, which he and his supporters in the Society for Bettering the Condition and Improving the Comforts of the Poor distributed to beggars throughout the capital. Each beggar was encouraged to attend the society's small office in Piccadilly, where the tickets were exchanged for $3 \mathrm{~d}$., "and frequently more," and the beggars asked for details of their background and circumstances. In less than seven months, Martin interviewed some two thousand individuals (who were themselves responsible for 3,096 children). Of this group, 198 were adult men, and the rest, over 90 percent of the total, were women. Six hundred further supplicants presented themselves but were turned away as paupers but not beggars. On the basis of these interviews, Martin eventually estimated that there were some 15,288 beggars working the streets of London, the vast majority of whom were women, frequently with children in tow. ${ }^{13}$ Even taking into account Martin's political imperative to present begging as a social problem, his figures suggest that many people, particularly women, could preserve a begging life without being significantly troubled by constables and watchmen and without becoming subject to the carceral ambitions of the state. So, while it is certainly true that many beggars were arrested, put to hard labor, and unceremoniously removed to their parish of origin, a much larger number appear to have been able to avoid the attentions of watchmen, constables, and outraged busybodies.

During this same period, the 1790s, according to Nicholas Rogers's detailed work on the implementation of the vagrancy statutes in London, approximately one thousand people a year were removed from Middlesex as vagrants, a proportion of whom were also put to hard labor. Among this group, women form a much smaller majority (approximately two-thirds as opposed to nine-tenths of beggars in Martin's sample), reflecting the selective and gendered implementation of the vagrancy statutes. As many of the people caught up in the law were in fact prostitutes, runaway apprentices, and alehouse louts, the number of street

${ }^{11} \mathrm{~T}-B-3$ - S Last Letter to His Witty Friends or Companions (London, 1718), 69.

${ }^{12}$ Henry Fielding, An Enquiry into the Causes of the late Increase of Robbers (London, 1751), 45.

${ }^{13}$ Matthew Martin, Letter to the Right Hon. Lord Pelham on the State of Mendicity in the Metropolis (London, 1803). 
beggars imprisoned and removed must have been relatively small. ${ }^{14} \mathrm{~A}$ measure of the limited impact the vagrancy laws probably had on beggars can be found in the records of the Court of Bridewell. In the twelve months between 1 May 1743 and 30 April 1744, 187 men, women, and children were committed to Bridewell for petty theft, sexual offenses, disorderly behavior, and begging, but the vast majority of these were accused of theft, prostitution, and disturbing the peace. Of this sample, the offenses committed by 122 individuals were actually recorded, and of these only five people were arrested for begging. And of these five, all were accused of significant social or legal infractions that went beyond simply asking for alms. Andrew Pearson and Barnaby Lyon, for instance, were arrested for begging, "pretending to have been shipwrecked \& wandering abroad with a counterfeit pass"; and a few months later William Burke was caught, "wandering and begging about the street \& particularly abusing Phil Gill . . . for refusing to relieve \& threatening to shoot him with a pistol." ${ }^{15}$ Simply begging on the streets did not generally warrant arrest and imprisonment despite the letter of the law and the tenor of elite commentary. Certainly, as a proportion of Matthew Martin's estimated 15,288 individuals, the beggars who found themselves before a magistrate facing a week of hard labor and a whipping must have felt very unlucky indeed.

In part, the explanation for the ability of beggars to maintain themselves on the streets lies in the complex patchwork of legal jurisdictions that made up the metropolis. Beggars could simply move from one parish to another, or from the City of London to Westminster or Middlesex and back, in response to changing patterns of prosecution. ${ }^{16}$ But, more importantly, the relative security of street beggars must be attributed to the attitudes of Londoners. The "mob" frequently took the side of the beggar. In the early nineteenth century, one witness before the House of Commons Committee on the State of Mendicity in the Metropolis reported that constables avoided arresting even the most flagrant street beggars because "the mob would often insist on their being set at liberty." ${ }^{17}$ But this public support for street beggars was only the tip of a much larger iceberg of complex negotiation and measured tolerance that extended from the cap-in-hand male beggar of elite disparagement, to women with children strapped to their backs, to the begging behavior of many street merchants, and finally to that of servants and apprentices

\footnotetext{
${ }^{14}$ Rogers, "Policing the Poor," 136-38.

15 "Court of Governors, Bridewell and Bethlem: Minutes, 12 January 1737/8 to 4 April 1751," Guildhall Library, MS 33011/21, 180-213. For the cases of Andrew Pearson, Barnaby Lyon, and William Burke, see 186 and 234. There were periods, during the mayoralty of Sir John Barnard in 1738-39, e.g., when beggars formed a substantially higher proportion of those committed to Bridewell, but this was an exception to the general rule. For an account of the workings of the court and its active role in policing the docks, see Peter D'Sena, "Perquisites and Pilfering in the London Docks, 1700-1795" (MPhil thesis, Open University, 1986), chap. 2.

${ }^{16}$ Moorfields was frequently cited as home to a large "concourse of disorderly persons and idle vagrants" and was subject to regular and apparently ineffectual presentments from the Grand Jury. See, e.g., Corporation of London Records Office (henceforth CLRO), "The Grand Jury's Presentment, 7 Jan 1739," Misc. MS 18/40. The position of Moorfields on the boundary between London and Middlesex must in part account for its popularity.

17 "Report of the House of Commons Committee on the State of Mendicity in the Metropolis, 1815," 64; quoted in Sidney and Beatrice Webb, English Poor Law History, Part I: The Old Poor Law, English Local Government (London, 1927), 371.
} 
who demanded regular tips and vails. The complex forms of self-presentation deployed by beggars and responded to by almsgivers can be understood as a fragment of the "moral economy" of the English crowd. As Edward Thompson suggested, "begging," like food riots, "is another learned response, or strategy." 18 But, whereas food rioters and smugglers could appeal to the collective authority of their neighbors, beggars were in a much less powerful position. They were forced to make subtler use of the assumptions of paternalism, the obligation of the rich to care for the poor. The only weapons in their armory were the shame and embarrassment of an alms refused or the pleasure of an alms freely given. This powerlessness sets them substantially apart from the rioters, smugglers, and poachers of a Thompsonian tradition. At the same time, the continuing success of beggars in maintaining a place on the streets, and in the hearts of almsgivers, reflects the extent to which the self-conscious adoption of Adam Smith's political economy remained a thin patina on the surface of English society well into the nineteenth century. ${ }^{19}$

The justifications that allowed so many to escape the attention of the authorities were rooted in agreed social mores that used the time of year, gender, age, race, and dis/ability as complex markers of a legitimate beggarly status. These distinctions and strategies were themselves then embedded within a complex economic continuum within which apprentices might beg and beggars might attempt to present themselves as legitimate laborers. Ritual begging on holidays, for example, has been consistently celebrated throughout Western history. Christmas, May Day, Guy Fawkes Day, and a plethora of more minor and tradespecific holidays and "dole days" in between formed an annual round of begging that marked good order rather than ill discipline. As John Gay described it, as Christmas neared:

Rosemary, and Bays and the Poet's Crown, Are bawled, in frequent Cries, through all the town.

At this time of year:

Cloth'd are the Naked, and the Needy glad, While selfish Avarice alone is sad. ${ }^{20}$

Of course, Christmas begging is still a common phenomenon. But in the eighteenth century the culture of holiday begging was both widespread and more central to the lives of the laboring poor than it has since become. One late seventeenthcentury pamphlet juxtaposed Christmas against fashion and pride, suggesting that

\footnotetext{
${ }^{18}$ E. P. Thompson, Customs in Common (London, 1991), 266.

${ }^{19}$ For a more anthropological approach to the social relations embedded in charity, see James C. Scott, Weapons of the Weak: Everyday Forms of Peasant Resistance (New Haven, CT, 1985).

${ }^{20}$ John Gay, "Trivia; or, The Art of Walking the Streets of London" (London, 1716), in John Gay: Poetry and Prose, ed. Vinton A. Dearing, vol. 2 (Oxford, 1974), lines 437-38, 449-50.
} 
a general hospitality at Christmas was the essence of good housekeeping and the first Christian duty. ${ }^{21}$

During the Christmas of 1735, John Sherwin, a particularly devout and upright apprentice to John Low in St. Brides, partook fully of the most widespread begging custom-the Christmas box. ${ }^{22}$ In the weeks between Old and New Christmas Day, he eagerly counted up his takings and, on a separate sheet of paper, listed who had given him how much, keeping careful track of the clinking coins in the box he hung by his place in the shop. By the last day of Christmas, he had accumulated around $£ 3$ in ready money-probably the single largest sum a London apprentice like Sherwin would see from one year to the next. ${ }^{23}$ The Christmas box, made of clay or tin with a single slot at the top or the side, formed an important symbol of Christmas, but more significantly, when it was broken open like a piggy bank and its contents shared among the apprentices, it gave meaning and substance to the season of good will and embedded every apprentice in an almost universal culture of begging.

As a result of patterns of apprenticeship, the Christmas box was a distinctly gendered phenomenon, used almost exclusively by young men and boys. Servants, who were overwhelmingly female, conducted their Christmas begging in a different way. Although they do not appear to have used the prop of a box, household servants still expected a gratuity from the tradesmen they dealt with in the dayto-day servicing of their families; while public servants-lamplighters, scavengers, delivery boys, and the like - could ask by right for Christmas alms from the householders who collectively employed them. ${ }^{24}$

In 1746, Isabella Hannah was a household servant to William Montegomery, an insolvent debtor, who lived in one of the raucous neighbourhoods adjacent to the river, in the East End. Come Christmas she haunted the area around the Inn of the Highlander by Pelican Stairs in Shadwell, doing the rounds of all the neighbors, and of her master's creditors, although she had been working for him only for a couple of months. When she came to William Smith, a lodger at Thomas Weymore's house some twenty yards away from Montegomery's, she asked for money for Christmas and was given half a crown. At first she went away, but she came back a little while later complaining that it was not enough. In the spirit of the season, Smith gave her a further sixpence. ${ }^{25}$

It is also clear that the annual boost to pauper incomes formed a central part

${ }^{21}$ See Poor Robin's Hue and Cry after Good House-Keeping. Or, a Dialogue Betwixt Good HouseKeeping, Christmas and Pride (London, 1687).

${ }^{22}$ The Oxford English Dictionary describes a Christmas box as "a box having a cleft on the lid, or in the side, for money to enter it; used . . . by butlers and prentices." For a brief account of the role of the Christmas box as seen from the perspective of financially secure men, see Margot Finn, "Men's Things: Masculine Possession in the Consumer Revolution," Social History (London) 25, no. 2 (May 2000): 149-50.

${ }^{23}$ Old Bailey Proceedings (henceforth $O B P$ ), 25 February 1736, Elizabeth Davis, t17360225-3, www.OldBaileyOnline.org.

${ }^{24}$ There is an excellent and growing literature on the history of eighteenth-century domestic service. See, e.g., Bridget Hill, Servants: English Domestics in the Eighteenth Century (Oxford, 1996); David A. Kent, "Ubiquitous but Invisible: Female Domestic Servants in Mid Eighteenth-Century London," History Workshop Journal 28 (1989): 111-28; Tim Meldrum, Domestic Service and Gender, 1660-1750: Life and Work in the London Household (Harlow, Essex, 2000).

${ }^{25} \mathrm{OBP}, 25$ October 1752, William Montegomery, t17521026-45. 
of their calculations. In Henry Carey's 1715 "Ballad of Sally in our Alley," the Christmas box is the key to the narrator's future happiness. The eponymous Sally is the daughter of a cabbage net maker, who:

\footnotetext{
through the streets does cry 'em

Her mother she sells laces long

To such as please to buy em.
}

The narrator is in love and requires nothing so much as enough money to marry his darling Sally. His one hope lies with the turning of the year:

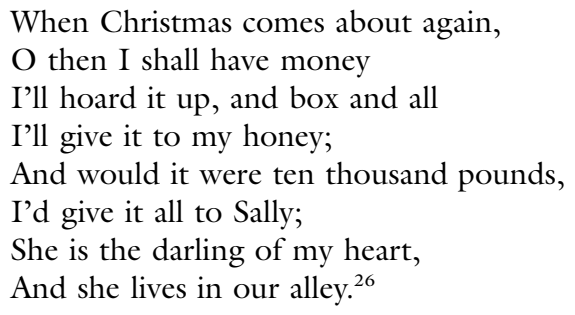

Nor was it just the actual Christmas box that was important. The extended early modern Christmas was a period in which all kinds of begging became more legitimate. Christmas carols were a pan-European phenomenon from the fifteenth century onward, and in London they provided a regular and predictable opportunity for organized begging. ${ }^{27}$ The governors of Christ's Hospital complained bitterly of the practice, and on 20 December 1727, the day before St. Thomas's Day, when the round of Christmas celebrations began, they gave "notice of an ill practice which prevails among the children of this house of going abroad to the houses of the governors and others in and about London especially at this season of year with a money box and the singing of carols in order to beg money. . . . To be stopped." ${ }^{28}$ Alternatively, a carefully positioned beggar by the church door after a Christmas service could not be refused. Indeed, the extent to which casual charity, putting "a penny in the old man's hat," forms perhaps the most important image in British Christmas folklore reflects again that Christmas normalized begging. Evidence of the extent to which the poor believed this is provided by the number of vagrants picked up in the month of December. In the one brief period for which we have a comprehensive list of vagrants for the City of London, most months of the year saw an average of fewer than nine examinations, while December saw over twenty. ${ }^{29}$ And while this may reflect the authorities' wish to draw a line between virtuous Christmas begging and vagrancy, it is clear that most other

\footnotetext{
${ }^{26}$ Henry Carey, "The Ballad of Sally in our Alley" (London, 1715?), reproduced in EighteenthCentury Verse, ed. Roger Lonsdale (Oxford, 1984), 138-39.

${ }^{27}$ See, e.g., Joel F. Harrington, “'Singing for His Supper': The Reinvention of Juvenile Street Singing in Early Modern Nuremberg," Social History 22, no. 1 (1997): 29.

28 “Christ's Hospital Almoner's and Rentors' Minutes," Guildhall Library, MS 12811/9, 20 December 1727. I would like to thank Dianne Payne for very kindly providing this reference.

${ }^{29}$ CLRO, "Vagrant Books, together with 5 loose pages and a bill of mortality, 1738-1742," Misc. MS 322.5.
} 
people could not. Thomas D'Urfey certainly saw few distinctions when in Collin's Walk Through London, he had one of his protagonists claim:

I came . . . of a good kind,

So much to charity inclin'd,

That even vagabonds and mumpers

Have from my bounty had full bumpers,

The blind and cripples in the street,

I've oft reliev'd with broken meat;

And many a Christmas Wassail Bowl,

Has felt the largess of my soul. ${ }^{30}$

Christmas, however, was just the most important and universally observed period of legitimized public begging. Throughout the year different holidays had their own rituals and customs, and public begging of one sort or another was a common aspect of several of them.

May Day was particularly important for milkmaids, chimney sweeps, bunters, and cinder sifters, and a popular subject for contemporary painters. Over the course of the eighteenth century, it gradually evolved to include props (Jack-in-the-Green was added around 1770) and to put ever more emphasis on the begging associated with the event. The increasing inclusion of boys and men in the festivities also had the effect of changing May Day's gendered nature from an event largely owned by women to one shared by both sexes. In 1817 John T. Smith looked back to the eighteenth-century May Day in his unique, urban picturesque account of London beggars, Vagabondiana, and bemoaned "the indecent conduct . . . [of men who] hire old dresses and join the chimney sweepers, cinder-shifters or Bunters' Garland . . . and exhibit all sorts of grimace and ribaldry to extort money from their numerous admirers." ${ }^{31}$ By contrast, in 1802 Robert Southey indulgently recorded how London chimney sweeps made an attractive sight on May Day: "Their table is spread under the May-pole; their playmates beg with a plate . . . and all dance round . . . hand in hand." 32 There is also some suggestion that the sweeps added a new character of menace to the day, using the threat of their own dirtiness to frighten middling-sort children and unwilling contributors. ${ }^{33}$

For both sweeps and milkmaids, the money raised, either through begging or more forceful persuasion, was an important part of their annual income. Milkmaids worked tremendously hard for a meager livelihood and suffered from chronic economic insecurity. And chimney sweeps, similarly, were at the bottom of the economic pile and would have looked forward to May Day with great anticipation. It also formed a marker in their economic year between winter, spent sweeping

${ }^{30}$ [T. D'Urfey], Collin's Walk Through London and Westminster. A Poem in Burlesque (London, 1690), 27.

${ }^{31}$ John Thomas Smith, Vagabondiana; or, Anecdotes of Mendicant Wanderers Through the Streets of London with Portraits of the Most Remarkable Drawn from Life (London, 1817), 41.

${ }^{32}$ Robert Southey, Letters from England, ed. Jack Simmons (Stroud, Gloucestershire, 1951), 80.

${ }^{33}$ Charles Phythian-Adams, "Milk and Soot: The Changing Vocabulary of a Popular Ritual in Stuart and Hanoverian London," in The Pursuit of Urban History, ed. D. Fraser and Anthony Sutcliffe (London, 1983), 100. 
chimneys, and summer, during which most sweeps were either unemployed or engaged as night soil men.

Other holidays brought less-structured opportunities to cadge a meal or a bit of cash. Easter, Hocktide, the duke of Cumberland's birthday, Rogation, Whitsun, Midsummer's Day, Bartholomewtide, the Lord Mayors' Procession, and Guy Fawkes Day on the fifth of November, along with a great many local and tradespecific dole days, all provided an opportunity for legitimate begging. Indeed, begging at the Lord Mayor's Procession was so commonplace that the City of London began to pay the parish poor to stay away. Payment of $£ 2.13 \mathrm{~s}$. $4 \mathrm{~d}$. is recorded in the City Cash Accounts each year throughout the eighteenth century, given to St. Margaret's to "keep the poor from following the Lord Mayor." ${ }^{34}$ Guy Fawkes Day, which came just a couple of weeks later, was, if anything, more carnivalesque and more important as an opportunity to raise some cash.

The precise contribution ritualized begging at holidays made to the economies of makeshift employed by the poor of London is impossible to determine. ${ }^{35}$ It is nonetheless clear that at least most children and young people below the elite felt entirely at ease with the notion of begging in this context. As importantly, when they did so, it was in company with street beggars. Like the students at Christ's Hospital, street beggars also sang carols at Christmas and knocked on doors expecting holiday alms. They followed along with the milkmaids and chimney sweeps on May Day and with the apprentices of London as they asked for a penny for the guy in the autumn. And because these ritualized begging events threw a secure boundary around specific forms of begging, they helped to protect regular and professional beggars from prosecution under the vagrancy laws.

This cultural immunity was true not just in relation to holiday begging. Early modern and eighteenth-century weddings were plagued by rough music and beggars. Pans and pots, bones and kettles were beaten and banged together below the windows of any newlywed couple. ${ }^{36}$ The cacophony would continue until the musicians were paid off with a few pence or shillings each. In Henri Misson's words: "If the drums and fiddlers have notice of it, they will sure to be with them by day-break, making a horrible racket till they have got the pence." ${ }^{37}$ In September of 1714 John Cannon, an improvident excise officer from Somerset, came to London in order to marry Susannah Deane. The next morning: "The City music smelled out our wedding and came early in the morning and played under our window. But our aunt prevented them to save our pockets, as well knowing their ways that if they were never so gratefully rewarded they disguising themselves would ingratefully return and send another company being confederates in rook-

\footnotetext{
${ }^{34}$ CLRO, "City's Cash Accounts, 1699-1701," MS 1/23, fol. 200.

${ }^{35}$ For a recent collection of essays devoted to the idea of an "economy of makeshift," see Steven King and Alannah Tomkins, eds., The Poor in England, 1700-1850: An Economy of Makeshifts (Manchester, 2003).

${ }^{36}$ On the roles of "rough music" in popular culture, see Thompson, Customs in Common, 467-531. For its role in marriage ceremonies, see in particular 470 n. 3.

${ }^{37}$ One early broadside claimed that butchers' apprentices monopolized this form of rough music; see His Majesty's Royal Peel of Marrowbones and Cleavers, Guildhall Library, Noble Collection C22/ 85, but most accounts suggest that a more diverse group of individuals was involved. Henri Misson, M. Misson's Memoirs and Observations in his Travels over England, trans. John Ozell (London, 1719), 352; see also John R. Gillis, For Better, for Worse: British Marriages, 1600 to the Present (Oxford, 1985), $68,138$.
} 
ing. So she told them the bride lodged not there [and] they passed off." ${ }^{38}$ John Cannon escaped without being forced to reward the musicians on his wedding morning, but most people considered it an act of hospitality and good cheer rather than an unreasonable duty.

In a similar way, funerals and Sundays offered opportunities for ritual begging. Sunday, of course, had a range of traditional associations with notions of Christian charity and neighborliness that made refusal to provide alms for beggars stationed at the church door particularly difficult. Several commentators suggested that professional beggars paid bribes to parish officers in order to gain access to this coveted position. The author of Low Life claimed that "small bribes [were] bestowed on beadles of parishes by common beggars for liberty to ask money at the church doors when the sermon is over." 39 Early modern funerals had also traditionally featured the distribution of alms, and there are examples of huge crowds of the poor gathering at the churchyard in order to collect their money. ${ }^{40}$

In other words, there were many times when it was impossible to say no. What ritual begging did was to make use of the rhetoric of Christianity, of hospitality, and of nationalism to prize open the closed hands of the financially secure. It also ensured that while the self-satisfied and powerful in this society might cavil at the begging knock at their front door or the pathetic plea at the street corner, they could not entirely condemn begging in all its forms. And of course, these varieties of minutely structured begging events formed only a small fragment of a larger phenomenon of financial redistribution. Day in and day out, begging provided the resources that a large proportion of the population actually relied on.

It is possible to minutely divide these varieties of begging into a series of separate phenomenon and to emphasize the undoubted distinctions between a Christmas box and a hat held in a "begging way." The former, for example, could readily be seen in the subtle light of the "gifts" anthropologists have done so much to explain. ${ }^{41}$ But the point of bracketing ritual begging with other types of appeals is to emphasize what they share (the redistribution of money and goods in response to carefully deployed rhetorical acts) rather than to draw attention to small distinctions that have traditionally allowed historians and other respectable members of Western societies to distance their own behavior from that of their beggarly fellows. For all practical purposes, ritual begging formed just one end of a spectrum of behaviors that tied lamplighters and apprentices, servants and the children of the better-off to the experience of the ragged and the unkempt. It reflected an aspect of economic behavior that was shared across the whole spectrum of what might be described as the gray economy. Begging, in its many forms, certainly played a significant part in the lives of the majority of Londoners who necessarily participated in an economy of makeshift-who built a supportable life from the

\footnotetext{
${ }^{38}$ John Cannon, "Memoirs of the Birth, Education, Life and Death of Mr John Cannon: Sometime Officer of the Excise \& Writing Master at Mere Glastenbury \& West Lydford in the County of Somerset" (1743), Somerset Record Office, MS DD/SAS C/1193/4, 115-19.

${ }^{39}$ Low-Life: Or One Half of the World Knows Not how the Other Half Live (London, 1749), 54.

${ }^{40}$ See, e.g., Lancashire and Cheshire Wills and Inventories, 1572 to 1696, Now Preserved at Chester, 2nd ser. (Manchester: Printed for the Chetham Society, 1893), 28:35.

${ }^{41}$ For an example of an attempt to apply anthropological insights into the nature of gift giving to the behavior of nineteenth-century beggars and paupers, see Roberts, "Reshaping the Gift Relationship."
} 
shards and fragments of a complex economy. And while the law certainly impinged more deeply on the less salubrious end of this spectrum of begging, this does not negate the strategies and assumptions they all shared.

What many achieved through holiday ritual, and the diurnal spaces of a complex calendar, other managed through the use of the begging professions. Ballad sellers, prostitutes, charwomen, and shoeblacks each hedged about their claims for relief with the rhetoric and reality of a useful occupation. Shoeblacks are particularly redolent of eighteenth-century London. Created as an employment only at the end of the seventeenth century, polishing the shoes of London's pedestrian throngs provided a perfect excuse for being on the street and for approaching passersby. John Gay, in his "Trivia," devotes some sixty lines to the origins and life history of a shoeblack:

The Child through various Risques in Years improv'd, At first a beggar's Brat, Compassion mov'd;

His Infant Tongue soon learnt the canting Art, Knew all the Pray'rs and whines to touch the Heart.

Until, that is, his goddess mother took pity on him and provided the tools of his new trade:

The Youth strait chose his Post; the Labour ply'd

Where branching Streets from Charing-cross divide;

His treble Voice resounds along the Meuse,

And White-hall echoes-Clean your Honour's Shoes. ${ }^{42}$

But the insecurity and near-begging nature of the shoeblacks' occupation is perhaps better caught in the records of the Court of Bridewell. In 1722, for instance, two young boys, Nathaniel Bear and William Walker, were tried as vagrants for "being very . . . idle and disorderly fellows pestering the streets by blacking shoes." ${ }^{43}$ The inclusion of shoeblacking as a vagrant occupation, along with the fact that there are only two instances in the Bridewell records of its being prosecuted, reflects both the legitimacy of street begging under the pretense of blacking and its clear association with mendicity.

If shoeblacks and chimney sweeps seem particularly evocative, reflecting the higher public profiles of male beggars, the most numerous working mendicants, and the group who most effectively confused the divisions between pauper employments and outright beggary, must have been the charwomen. All records of eighteenth-century begging suggest that women (and women with children in particular) dominated the rolls of London's ragged crew. Both Matthew Martin's contemporary statistics and Nicholas Rogers's modern reconstructions confirm the extent to which women far outnumbered men on the streets and in the records

\footnotetext{
${ }^{42}$ Gay, "Trivia," vol. 2, lines 141-44, 213-16.

43 "Court of Governors, Bridewell and Bethlem: Minutes, 26 October 1722 to 15 December 1737," Guildhall Library, MS 33011/20, 27 March 1724, 26.
} 
of legal persecution. At the same time, women knocking gently on London's kitchen doors seeking work or charity were largely beyond reproach. On most days the more salubrious parts of town were full of women going from door to door asking first and foremost for a bit of work and accepting broken food when their virtuous supplications went unanswered. These were women like Ruth Child, who in the late 1750s regularly knocked on the door of Ann Murray in Greek Street, Soho. Murray later testified that Ruth "stood at my door for charity, she had neither shoes nor hardly any thing else that could be call'd apparel; I used to take pity on her, and gave her some cold victuals, and an old petticoat, and an old curtain to make her a gown, and other things, and sometimes money, and in return she wash'd my door down; I let her go down into my kitchen to get some victuals which was cold lamb." 44

With the development of a separate floor for the kitchen and services, with the arrival of the "area," with its stairs and wrought iron, charwomen frequently found themselves dealing with more established servants rather than with the master or mistress. ${ }^{45}$ The ambiguity of the situation is caught perfectly in the difficult advice meted out to young servants by Eliza Haywood in her 1771 New Present for a Servant-Maid. In relation to giving away victuals, Haywood says that "charity and compassion for the wants of our fellow creatures are very amiable virtues," but advises that servants need the permission of their mistress before the dole is given. In other words, she essentially approves of charity in kind distributed at the kitchen door. On the issue of charwomen she is more censorious and suggests that the common practice of giving "them victuals for helping you" would lead to all kinds of problems and introduce the possibility of theft. ${ }^{46}$ In the end, it is clear that charring made foggy and indistinct the boundary between begging and service. Sarah Churchill came begging at the door of Frances Norris in October 1722. She had just come out of Marshelsea, where she had been imprisoned for debt, and appealed for work as a char. She was given a night's accommodation before leaving the next day with several items not actually belonging to her carefully concealed about her person. ${ }^{47}$

In a perhaps similar way, begging and prostitution were intimately linked. Mary Price, the twenty-three-year-old wife of a tallow chandler in St. Martin in the Fields, combined begging in the western reaches of London with casual prostitution. She had sex with the improbably named Francis Gotobed and later claimed that "she had had many a shilling and sixpence of him and had it not been for him should have half starved." 48 And the standard approach by a prostitute-a gentle (or not so gentle) tug on the sleeve, with a "How do you do, Countryman; Will you give me a Pint of Wine?"-is at least superficially a plea for charity. Mary

${ }^{44}$ OBP, 28 February 1759, Ruth Child, t17590228-14.

${ }^{45}$ For an accessible account of the development of the "area," see Dan Cruickshank and Neil Burton, Life in the Georgian City (London, 1990), chap. 1.

${ }^{46}$ E. A. Haywood, A New Present for a Servant-Maid: Containing Rules for her Moral Conduct both with Respect to Herself and her Superiors: The Whole Art of Cookery, Pickling, Preserving (London, 1771), 11 .

${ }^{47} \mathrm{OBP}, 10$ October 1722, Sarah Churchill, t17221010-22.

${ }^{48}$ Quoted in Faramerz Dabhoiwala, "The Pattern of Sexual Immorality in Seventeenth- and Eighteenth-Century London," in Londinopolis: Essays in the Cultural and Social History of Early Modern London, ed. Paul Griffiths and Mark Jenner (New York, 2000), 95. 
Long accosted Christopher Hall in Drury Lane one early December night in 1717 with just this expression. She and her companion were dressed in rags and with Hall went to a private room at the Fountain Tavern. A third woman, equally ragged, joined them there. Hall sat at one end of the room, bought drinks for all three women and eventually allowed or encouraged Mary Long to masturbate him to orgasm. The literally arm's length relationship between Mary Long and Christopher Hall speaks strongly to the cultural as well as the physical distance between the two. But prostitution, in this instance, seems more akin to begging and charring than to anything that could be equated with sex. ${ }^{49}$

Mary Long was self-consciously exchanging sex for wine, but begging by women and approaches by prostitutes were so linked in the public mind that beggars were simply assumed to be sexually available. Sarah Griffin was begging her way from London to Worcestershire with a pass and a few pence in her pocket when, in September 1740, she asked seventeen-year-old William Duell for directions to where she could sleep for the night. Having been sent to a local barn near an alehouse, she was awakened a couple of hours later by Duell and five or six other young men, including George Curtis, alias Tug-mutton. They had come to the barn expecting sex and despite her claim to be poxed, her poverty, and her pleas and cries of murder, they brutally gang-raped her, leaving her to die slowly over the next few days. Having each raped her, they adjourned to the alehouse next door to spend her meagre supply of cash. ${ }^{50}$

Beyond the perhaps straightforward instances of prostitution and shoeblacking, the beggarly professions came in an almost unlimited variety. Each season had its trade, each circumstance its possibility. The mackerel sellers came out in the late winter and spring, and the peddlers set off in spring and summer. Whether you cried oysters or cabbage nets, sold laces or mended pots and pans, the assumption was always that begging was a part of one's activities; that any spare food, or old clothing, any spare cash or spare kind, would be picked up and reused. Israel Potter, who cried "old chairs to mend" and who recycled the rags, glass, and nails he found upon the streets in the 1780s and 1790s, claimed that when his luck was particularly low: "Such indeed was sometimes our miserable appearance, clad in tattered garments, that while engaged in our employment in crying for old chairs to mend, we not only attracted the notice of many, but there were instances in which a few half pennies unsolicited were bestowed on us in charity." ${ }^{51}$ Little of this casual begging was subject to the workings of the vagrancy laws, and at times, it was positively encouraged by outposts of the eighteenth-century state. In 1677 St. Martin's determined to allow its pensioners “to aske and receive broken meate only and not to beg of coaches or of people going in the streets, and the hours of asking at doores allowed are from one to foure in the afternoon and noe

\footnotetext{
${ }^{49}$ OBP, 11 January 1717, Mary Long, t17170111-18. For an excellent recent account of prostitution in eighteenth-century London, see Tony Henderson, Disorderly Women in Eighteenth-Century London: Prostitution and Control in the Metropolis, 1730-1830 (London, 1999).

${ }^{50} O B P, 15$ October 1740, William Duell, t17401015-53.

${ }^{51}$ Israel R. Potter, The Life and Remarkable Adventures of Israel R. Potter, with an introduction by Leonard Kriegel (1824; New York, 1962), 78, 94; citations from 1962 edition.
} 
longer, and none are to aske at doores without a badge." ${ }^{52}$ Indeed, the perhaps least studied but most revealing piece of poor-law legislation to emerge in the long eighteenth century, the Badging Act of 1697 , can be read a number of different ways. ${ }^{53}$ It is well known that the poor disliked the badges, which identified them as members of the parish poor, but what is less frequently remarked upon is that the badges acted as a license to beg in one's own parish. There are even instances in which parishes encouraged the badged poor to spend their days begging at the local crossroads as a way of supplementing their parish pensions. For a very brief period in the autumn of 1705 , the Governors of the Poor for London, for instance, recorded the place of settlement of everyone apprehended for vagrancy and whether or not they were in receipt of a parish pension. Of twenty-nine individuals apprehended for begging in October 1705, six of them were in receipt of parish pensions at the time of their incarceration. They were people like Katherine Archer, a fifty-year-old resident of Whitechapel, who was arrested for begging by the warder of Bishopsgate. She was in receipt of twelve pence a week from her parish. Or William Stephenson, a forty-three-year-old blind man who lived in St. Martin in the Fields, who was arrested with his wife Katherine "idle \& begging ... .[in] Tower Ward." He and his wife received eighteen pence a week from his parish. The crime committed by these individuals was not begging per se, but begging outside their own parishes of settlement. ${ }^{54}$

What all of the beggars surveyed so far had in common was their ability to use one or another well-established narrative strategy to ensure that their begging was seen in the light of either custom or service. They were the local poor, and hence deserving, or hardworking chars and street sellers, or even harder working prostitutes, demonstrating their real need by their willingness to sell sex for money. Or else they were carolers and May Day dancers, skimming the financial substance from the frothy good cheer of communal celebrations. They were playing highly gendered and occupationally specific roles (of domestic servant, seduced victim, or abandoned child) that ensured that watchmen and constables allowed them to go about their business-that they would be seen as a normal component of any street scene rather than in the light of a dangerous vagrant. In part, the disparity between the disparaging rhetoric of social policy reformers who bemoaned the existence of beggars on the streets and the reality of so many beggars' lives is a reflection of competing visions of social obligation and economic function. Beggars reflected the continuing relevance and authority of an older tradition of Christian charity dispensed to one's neighbors. Here was the substance of a moral economy. In contrast, the ever more hectoring antibegging rhetoric, and the substance of the institutions established in the form of that rhetoric, appealed to a new political economy in which exchange was to be disciplined in a marketplace in which the price of empathy could not be set.

\footnotetext{
${ }^{52}$ Quoted in Jeremy Boulton, "Going on the Parish: The Parish Pension and Its Meaning in the London Suburbs, 1640-1724," in Chronicling Poverty: The Voices and Strategies of the English Poor, 1640-1840, ed. Tim Hitchcock, Peter King, and Pamela Sharpe (London, 1997), 33.

${ }^{53} 8$ \& 9 William III, c. 30 (1697). For a recent article tracing the history of badging that presents a notably pessimistic view, see Steve Hindle, "Dependency, Shame and Belonging: Badging the Deserving Poor, c. 1550-1750," Cultural and Social History 1 (2004): 6-35.

${ }^{54}$ See CLRO, "Courts of the President and Governors of the Poor of London, 1702-5," MS New $377 \mathrm{c} / 1 / 22$, fols. $246-47$.
} 
The existence of ongoing attempts to police beggars and begging suggests that there were limits to the ability of individuals to defend their place on the streets. Indeed, one could argue that the phenomenon explored so far survived and flourished precisely because they were not begging, that these were people who would not have been defined as "beggars" by an eighteenth-century lexicographer. But even the flagrant street beggars, men and women, with caps in their hands, children strapped to their backs, and curses on their lips, were not always prosecuted, and they continued to form a normal part of every street scene.

The existence of a whole raft of well-known beggars is perhaps the best testimony to the ability of even cap-in-hand beggars to maintain a supportable social position. "Phillip in the Tub," the "Scarecrow," and Ambrose Gwinett are just three beggars who managed to carve for themselves a secure position on both the streets of London and in the art and literature of the period. John Thomas Smith's 1817 Vagabondiana details, illustrates, and effectively romanticizes the lives of over thirty well-known London beggars, suggesting again the extent to which cap-in-hand begging for money on the street was tolerated at the same time that the history of social policy would lead us to expect brutal suppression. Published in the wake of the passage of the 1822 Vagrancy Act, Charles Lamb's essay "A Complaint of the Decay of Beggars in the Metropolis" suggests again the existence of an ambivalent but real sense of connection between writers like Smith and Lamb and the street beggars of London-a relationship recognized and discussed only after nineteenth-century legislation had begun to sweep beggars from the streets. ${ }^{55}$ These works form an aspect of what can be described only as the "urban picturesque." There is no question but that both authors, like Henry Mayhew and the early photographers of London's street people, actively selected and misrepresented the subjects of their depictions. ${ }^{56}$ Their textual and visual sketches are full of pathos and humor in equal measure, and they pick out an entirely unrepresentative sample of adult, frequently elderly, male beggars from a group up to 90 percent of which were women. Nevertheless, the careful depictions of specific beggars, the existence of whom can be verified from a variety of admittedly literary and newspaper sources, provides evidence for the substantial cultural place awarded to at least those beggars capable of conforming to a demanding stereotype.

The ability of many professional beggars to create a space of relative security for themselves is reflected in the experience of people such as Nicholas Randall. He was an old man and "a beggar," who regularly stationed himself at the "pissing

\footnotetext{
${ }^{55}$ John Thomas Smith, Vagabondiana; Charles Lamb, "A Complaint of the Decay of Beggars in the Metropolis," Essays of Elia (London, June 1822). On the 1822 Vagrancy Act and social policy, see Roberts, "Reshaping the Gift Relationship"; M. J. D. Roberts, "Public and Private in Early Nineteenth Century London: The Vagrant Act of 1822 and its Enforcement," Social History (London) 13 (1988): 273-94.

${ }^{56}$ On the selective strategies of nineteenth-century social reformers, see Tim J. Barringer, "Images of Otherness and the Visual Production of Difference: Race and Labour in Illustrated Texts, 1850-1865," in The Victorians and Race, ed. Shearer West (Aldershot, 1996), 34-52; Thomas Prasch, "Photography and the Image of the London Poor," in Victorian Urban Settings: Essays on the NineteenthCentury City and Its Contexts, ed. Debra N. Mancoff and Dale J. Tela (New York, 1996), 179-94.
} 
place going to Brentford." His success as a professional is reflected in his house. Despite being a beggar, he lived by himself in a small house with a garden at Turnham Green. By the side of the highway there, he "has a little house . . . and a garden a little distance from it," with "two pear-trees, a damson tree, and two or three apple trees in it." ${ }^{57}$ In a similar way, Simon Edy lived for decades in Dyot Street and begged in front of St. Giles's churchyard. He achieved the perhaps dubious distinction of being drawn several times by Thomas Rowlandson and of having a full-length portrait published as an etching by John Seago above a legend: "Simon Edy, born at Woodford near Thrapston, Northamptonshire, in 1709: died May 18, 1783." John Thomas Smith later recalled his way of life:

Old Simon . . . wore several hats at the same time suffered his beard to grow, which was of a dirty yellow-white. Upon his fingers were numerous brass rings. He had several waistcoats and as many coats, increasing in size, so that he was enabled by the extent of the uppermost garment to cover the greater part of the bundles containing rags of various colours; and distinct parcels with which he was girded about, consisting of . . . cuttings of curious events from old newspapers; scraps from Fox's Book of Martyrs and three or four dog-eared and greasy thumbed numbers of the Gentleman's magazine. ${ }^{58}$

Perhaps more typical of the experience of London's better-established and professional beggars is that of Samuel Badham. In around 1732 he was struck down by illness, which meant he could no longer wear shoes. His wife died, and with "a thick bundle of rags tyed under the soles of his feet, and with a stick in each hand," he set himself up as a beggar. The pattern of his life was soon well established; he would go out for several days at a time, staying in cheap lodgings at night and begging about the streets in the daytime, "picking up what I could get in the Way of Charity" by using "a great many Scripture words." One night at the "Sign of the Crooked Billet in Hog-Lane," deep in the poorest part of St. Giles, he met Susannah Hart. Although Susannah was already married, they set up house together and later had a child together. This way of life went on for eight years. Susannah made her living by sweeping "the doors before gentlemen's houses in Rathbone-Place, and go[ing] on Errands for the Servants," while Samuel continued his rounds of London. Susannah was an alcoholic and accidentally killed their child, crushing it in a drunken sleep. She was also the more successful of the two, bringing in more money to the household. There is no evidence, however, that Samuel was ever arrested for vagrancy or removed from the city. He was able to pursue a regular and untroubled career for almost a decade, until in 1740, he murdered Susannah with his bare hands, was tried at the Old Bailey, and hanged at Tyburn. ${ }^{59}$

In part, Badham's immunity to prosecution for begging must have resulted from the repulsive state of his feet, but it is clear that you needed to do something

${ }^{57}$ OBP, 12 September 1759, Nicholas Randall, t17590912-22.

${ }^{58}$ John Thomas Smith, A Book for a Rainy Day; or, Recollections of the Events of the Last Sixty Years (London, 1845), 72-74.

${ }^{59}$ The Ordinary of Newgate's Account (London), 6 August 1740; OBP, 9 July 1740, Samuel Badham, t174000709-2. 
quite unusual to find yourself prosecuted under the vagrancy laws. For most beggars, appealing to the protection of broadly shared social attitudes toward disability and gender, custom and utility was enough to keep the rough fingers of the law from their collars.

If anything, public responses to begging became more sympathetic over the course of the century. New strategies to justify begging and the presence of the begging professions on the streets emerged in almost every decade. The large number of black refugees from slavery and America whose presence as beggars on the streets of London was widely tolerated from the 1780s is a case in point. ${ }^{60}$ The ill-fated Sierra Leone colonization scheme of 1786-91 was in part intended to rid London of its black poor and of its black beggars in particular, but Londoners continued to perceive the black poor as a deserving subgroup of beggars. ${ }^{61}$ John Clare's emotional reaction to his first encounter with a black beggar near St. Paul's speaks powerfully of the role of race in creating a begging persona. "The sincerity of his distress spoke plainer than words. I felt my pockets but I had only four pence in all and I felt almost ashamed to receive . . . thanks for so worthless a pittance." $" 62$

Soldiers and sailors could also rely on the sympathy of the broader population. The last quarter of the eighteenth century in particular is replete with military accounts by male beggars - tales frequently written out on the pavement, or on cards, or in ballads ready to be sold and sung, or expressed in the more subtle language of a ragged uniform and empty sleeve. This was begging designed to appeal to the politics of a racially inflected antislavery movement and to the emotions of a newly rampant nationalism. But it was also begging that built on a centuries-old tradition of allowing soldiers and sailors, and their families, to beg their way homeward from war. A military pass of a sort that could be issued by any justice of the peace provided almost complete protection from prosecution as a vagrant. Ironically, even the foundation of institutions such as the Royal Military Hospital at Chelsea did more to increase the number of military beggars on London's streets than to reduce it. The vast majority of pensioners supported from the hospital, up to a thousand men, were "outpensioners" who received their doles only once a quarter. These men, frequently accompanied by their families, were forced to travel to London in order to collect their quarterly payments. In the process, the presence of these veterans, whose right to relief could not be questioned, helped to create a space that other male beggars could also occupy ${ }^{63}$ The men who took advantage of this begging space were people like Thomas Dargaval, who in the chill of November 1782 was picked up for vagrancy in London. He was around twenty-three years old. He had grown up in Liverpool and was apprenticed to the sea at the age of twelve. For nine years he served in merchantmen, first as an apprentice and then before the mast, until he was discharged in around 1780 at Port Royal, Jamaica. At this point he signed on to a ship operating under

\footnotetext{
${ }^{60}$ On the "black poor," see Stephen J. Braidwood, Black Poor and White Philanthropists: London Blacks and the Foundation of the Sierra Leone Settlement, 1786-1791 (Liverpool, 1994).

${ }^{61}$ For the Sierra Leone settlement, see Braidwood, Black Poor and White Philanthropists.

${ }^{62}$ John Clare, John Clare's Autobiographical Writings, ed. E. Robinson (Oxford, 1986), 140-41.

${ }^{63}$ For a brief discussion of the relationship between the hospital and local poverty, see Tim Hitchcock and John Black, eds., Chelsea Settlement and Bastardy Examinations, 1733-1766, London Record Society, 33 (1999), xv.
} 
letters of marque out of Bristol. On the voyage back to Britain, the ship, the Vigilant, was attacked by two French men-of-war, and Thomas was wounded by canister shot from one of the attacking vessels, losing his right arm to the surgeon's knife. A prisoner in Brest for eleven months, he considered his predicament and asked the ship's carpenter for help. Together they made a small wooden model of the Vigilant, and Thomas took it with him when he was finally exchanged. Discharged onto the streets of Dover in February 1782, Dargaval quickly set to work making use of the wooden model. For the next ten months he traveled about showing the ship to whoever would look and telling his story to whoever would listen, and in the process he squeezed a modest income from the hard hearts of a war-weary populace. The remarkable thing about Dargaval's story is the selfconscious way in which he manipulates and builds on his own account in order to appeal to a broader public sympathy. ${ }^{64}$

In a very real way, it is the self-consciousness that forms the point of this article. What all the beggars described above-the apprentices and servants, the shoeblacks, chars, and cap-in-hand mendicants-have in common is the ability to construct in words and symbols a sophisticated and undeniable claim to the alms of men and women, servants and gentlemen. They possessed the ability to deploy fragments of a series of cultures of obligation that cut across the condemnation of begging found on the statute books.

The stories beggars told and the ways in which they differentiated themselves from the disastrous label of "vagrant" depended on gender, age, and ability. There is, for instance, a clear gendered element in both the perception of beggars and the nature of most claims to relief. All of the street beggars (as opposed to participants in the begging professions) detailed above were men. There are virtually no individual women in the literary accounts of London's beggars, despite the fact that the vast majority of people begging on the streets, and to a slightly smaller degree taken up by the authorities under the vagrancy laws, were women. In part, this reflects the different roles of disability, pregnancy, and parenthood in the construction of begging. Women frequently used the evidence of motherhood (both pregnancy and small children) as a part of a compelling narrative of need. At the same time, their disabilities (perhaps the most powerful justification for begging men were able to deploy) were less effective for women. Women's clothes hid many of the signs of disability more apparent in male attire, and while men's birth defects and industrial accidents could be recast as the result of a military adventure, this narrative strategy was not open to women. Begging also mapped on to contemporary gendered perceptions in complex ways. A secure masculinity, for instance, could be rooted in military valor or sincere religiosity — characteristics that could be claimed by the most ragged mendicant. ${ }^{65}$ But femininity was much

\footnotetext{
${ }^{64}$ CLRO, London Sessions Papers, December 1782, "31 Examinations of Supposed vagrants"; see the examination of Thomas Dargaval, 16 November 1782.

${ }^{65}$ For an account of the role of religion in the construction of eighteenth-century masculinity, see Jeremy Gregory, "Homo religiosus: Masculinity and Religion in the Long Eighteenth Century," in English Masculinities, 1660-1800, ed. Tim Hitchcock and Michele Cohen (London, 1999), 85-110.
} 
more strongly tied to the roles of honest servant, good wife, good daughter, good mother. Charring and begging with children appealed to at least two of these roles, but collectively they effectively debarred women from the high-profile role of the public beggar. Male disability also justified a long-term presence on the streets that allowed men to become "characters," while female narratives, embedded more fully in the life-cycle events of parenthood, could justify begging for only a limited period. In a similar way, age (both extreme youth and old age) inflected the stories told by beggars. The gray hairs and lined faces of elderly beggars, for instance, compensated for an able body and missing children.

When you consider the screeds of dense prose given over to the history of social policy, the development of the legislative framework that supposedly ensured that each beggar was whipped and confined at hard labor in Bridewell before being unceremoniously shipped to their parish of settlement, the ability of both highly visible male beggars and the much more numerous female beggars to maintain themselves on the streets of eighteenth-century London is remarkable. If the institutions of the eighteenth-century state - the workhouses and hospitals, bridewells and prisons-did not shape and confine the activities of the beggarly poor, we need to reassess what in fact they did do.

At the same time, the success of the poor in continuing to beg draws our attention to the authority of a range of competing rhetorics and worldviews. The teleological nature of history as a discipline frequently leads us to overestimate the impact of new ideas. In the case of begging, we are confronted with a phenomenon that helps to remind us of the continuing importance of a moral economy in determining the everyday behavior of individual men and women. However compelling the new discourses of capitalism and utilitarianism might have been, most people, both beggars and almsgivers, continued to respond to the claims of social obligation and Christian charity. In the process, beggars were able to use subtly the varied rhetorics of social obligation to force the hands of their social superiors.

What the realities of begging demonstrate is that the rhetorics of social order do not exist as a single hegemonic and all-enveloping phenomenon; that when one adds the dimensions of time and space, gender, age and dis/ability to that overexplored artifact language, what emerges is a furious and constant battle between innumerable competing claims. The claims of the poor, their use of the diurnal spaces around Christmas and May Day and of "scripture words," and the assumptions of the stark categories of masculinity and femininity allowed beggars to battle against the rising tide of condemnation and regulation.

For the eighteenth century at least, beggars continued to hold center stage. Every penny given to beggars, with their whining appeal and ragged clothes, their snotty children, missing limbs, and pathetic tales, represented a successful defense against the Enlightenment. Each farthing was a stone thrown at Adam Smith and Jeremy Bentham and their many followers who sought to turn paupers and criminals into simulacra of elite thinking. In the short term, no amount of stone and mortar, no neoclassical prison and hospital, could overcome the power of the poor to claim by right the sympathy and aid of their fellow human beings. In other words, to understand the eighteenth century, and the transition to the nineteenth, we need to reinsert the male beggar on the street corner, the female pauper at the door. We need to recognize that social policy is not made by Parliamentarians, 
pamphlet writers, and elite philanthropists alone. Instead, it is a result of a profound conflict between two classes of individuals, neither of whom can foresee or control the eventual outcome. We need to recognize that while in the short term the rich could choose which beggar to give to, which plea to answer, they could not, and did not, either control or deny the claims of beggars as a whole. The poor, for their part, could and did insist that something was given, that the rich live up to their obligations. They were empowered to make a claim that embarrassed and cajoled, that pushed the well-to-do this way and that. And if in the end, the forces of state regulation largely won out over the cultures of mutual obligation, the acts of both asking and giving alms continued to be freighted with historical significance.

But, to end with a beggar, or at least someone who aspired to begging: Elizabeth Evans was probably a prostitute-at least when asked about the father of her bastard daughter, she named three or four possibilities-but more importantly, she was a woman living at the edge of London society. She shared a bed with Sophia Claxton in a cheap lodging house and on the night of 9 February 1740 went into labor. She did not tell her bedfellow, but in the morning Claxton found the dead body of a newborn female infant wrapped in a linen cloth. The midwife was called, and Evans was taxed with the death. She vehemently denied it, asserting that the child was born dead, but in her defense also said that "she found it dead, and therefore laid it away from her; and before she would have killed it, she would have gone a-begging with it." ${ }^{\circ 6}$ Begging, for Evans and for most working people in eighteenth-century London, was a realistic and even attractive proposition. A young baby was a prop to female begging so powerful that many claimed there was a well-established rental agency to satisfy the demand somewhere in the depths of St. Giles. ${ }^{67}$ Presented with a child, Evans's first thought was how she could use the baby to construct a begging persona to access the resources her new position as a pauper mother would then deserve.

${ }^{66} \mathrm{OBP}, 16$ April 1740, Elizabeth Evans, t17400416-24.

${ }^{67}$ See, e.g., A Trip From St James's to the Royal-Exchange: With Remarks Serious and Diverting on the Manners, Customs and Amusements of the Inhabitants of London and Westminster (London, 1744), 25-26. 